\title{
Jejunal duvar kalınlaşmasının nadir bir nedeni: Primer seröz papiller peritoneal karsinoma
}

\author{
A rare cause of jejunal wall thickening: Primary peritoneal serous papillary carcinoma
}

\author{
Banu Demet COŞKUN', Eylem SEVINÇ² \\ ${ }^{1}$ Kayseri Eğitim ve Araştırma Hastanesi, Gastroenteroloji Kliniği, Kayseri \\ ${ }^{2}$ Karabük Üniversitesi Tıp Fakültesi, Çocuk Gastroenteroloji Bilim Dalı, Karabük
}

\begin{abstract}
Primer seröz papiller peritoneal karsinoma, peritonun nadir görülen bir adenokarsinomudur ve histolojik özellikleri overin seröz papiller karsinomu ile benzerdir. Ancak primer seröz papiller peritoneal karsinomada tipik olarak overler normaldir. Sıklikla postmenapozal kadınlarda (ortalama yaş 55-65) görülür. En sık görülen bulgular asit ve karsinoembriyonik antijen-125 yüksekliğidir. Abdominal bilgisayarlı tomografi ve manyetik rezonans görüntülemelerde asit, peritoneal kalınlaşma, omental kek ve intraabdominal kitle görülen bulgulardır. Bu yazımızda jejunoileal duvar kalınlaşması ve asit ile başvuran ve primer seröz papiller peritoneal karsinoma tanısı alan olgu sunuldu. Literatürde jejunaileal tutulum ile prezente olan ilk vakadır.
\end{abstract}

Anahtar kelimeler: Primer seröz papiller peritoneal karsinoma, jejunoileal duvar kalınlaşması

\section{GíRiş}

Primer seröz papiller peritoneal karsinoma (PSPK) nadir görülen abdomen veya pelvikperitoneal yüzeyden kaynaklanan bir adenokarsinomdur. Swerdlow ve arkadaşları tarafından ilk kez 1959 'da yeni bir tümör antitesi olarak tanımlanmıştır (1). Gerçek insidansı bilinmemektedir, ancak over kanserlerine göre sıklı̆ı 1/10'dur (2). Çoğunlukla kadınlarda görülmesine rağmen erkeklerde de görülen olgular rapor edilmiştir $(3,4)$. Sıklıkla yaşlılarda (ortalama yaş 55-65) ve postmenapozal kadınlarda görülür. Tümör histolojik, sitolojik ve immünohistokimyasal özellikler bakımından overin seröz papiller karsinomu ile benzerdir. Ancak PSPK tipik olarak normal görünümlü overlerin varlığı ile karakterizedir. Hastalar tipik olarak karın ağrısı, abdominal distansiyon, asit, bulantı ve kusma gibi subileus şikayetleri ile başvurabilirler (5). Bu yazımızda jejunoileal duvar kalınlaşması ve asit ile başvuran hastalarda PSPK'ında akılda tutulması gerektiğini vurgulamak istedik. Literatürde jejunaileal tutulum ile prezente olan ilk vakadır.

\section{OLGU SUNUMU}

Elli sekiz yaşında kadın hasta 1 aydır devam eden epigastrik ağrı, dolgunluk hissi, tekrarlayan kusma ve kilo kaybı (5 kg) nedeniyle gastroenteroloji servisine yatırıldı.
Primary papillary serous carcinoma is a rare neoplasm of the peritoneum and is histologically similar to papillary serous carcinoma of the ovary. However, the presence of ovaries is quite common in primary papillary serous carcinoma. It is predominantly present in postmenopausalwomen (mean age, 55-65 years). The most common clinical findings are ascites and elevated carcinoembryonic antigen 125. Radiological findings, such as computed tomography and magnetic resonance imaging, on the abdomen showed ascites, peritoneal thickness, omental cake, and intra-abdominal mass. In this abstract, we are presenting the clinical findings of apatient with primary papillary serous carcinoma along with jejunoileal wall thickening and ascites.

Key words: Primary papillary serous carcinoma, jejunoileal wall thickening

Hastanın özgeçmişinde 30 yıldır diabetes mellitusu (DM) olduğu ve son 4 yıldır diyabetik nöröpatiye bağı düşük ayak nedeniyle takip edilmekte olduğu ögrenildi. DM için insülin ve diyabetik nöropati için gregabalin kullanmakta idi. Hastanın fizik muayenesinde konjonktivalar soluk ve cilt yaygın hafif ödemli idi. Hastanın vital bulguları stabil idi. Hastaneye kabulünde bakılan laboratuvar tahlillerinde beyaz küre (WBC): 8190/ $\mathrm{mm}^{3}$, nötrofil \%70, hemoglobin: $10 \mathrm{gr} / \mathrm{dl}$, ortalama eritrosit hacmi (MCV): 85 , total protein: $5,1 \mathrm{gr} / \mathrm{dl}$, albümin: $2,7 \mathrm{gr} / \mathrm{dl}$, sodyum: 127 , sedimentasyon: 6, C-reaktif protein (CRP): 4 idi. Idrar tetkikinde glukozüri dışında özellik yoktu. Serum tiroid stimüle edici hormon (TSH): düzeyi $1,2 \mathrm{ng} / \mathrm{dl}$ idi. Hastanın üst endoskopisi normaldi. Diyabetik gastroparezi düşünülerek sintigrafik mide boşalma hızı ölçüldü ve normal olarak raporlandı. Batın ultrasonografi (US) normal olarak değerlendirildi. Çekilen tüm batın magnetik rezonans görüntülemede yaygın jejunoileal anslarda inflamatuvar duvar kalınlaşması tespit edildi (Resim 1,2).

Bilgisayarlı tomografi anjiografik incelemede mezenterik arter ve venler açık olarak yorumlandı. Kolonoskopi ile ağızdan girilerek jejunumun 1/3 proksimaline kadar ilerlendi. Endoskopik bakıda jejunumda $4-5 \mathrm{~cm}$ aralıklarla 
mukozada sirküler tarzda eritemli alanlar izlendi ve biyopsi alındı. Jejunal biyopsi mukozal ödem olarak raporlandı. Hastanın izlemi esnasında vücutta yaygın ödem ile birlikte plevral mai ve asit gelişti. Asit örneklemesinde serum asit albümin gradienti: 0,8, assitadenozindeaminasyon (ADA) $5 \mathrm{mg} / \mathrm{dl}$, EZN boyaması ile ARB (-), tüberküloz PCR negatif, asit sitoloji class II olarak raporlandı. Tümör markırlarından karsinoembriyonik antijen (CEA): 75 (normal, <3 IU/ml), kanser antijeni (CA)-125: 835 (normal, < $20 \mathrm{U} /$ $\mathrm{mL}$ ) idi. Kadın doğum muayenesinde adneksiyel yapılar normal olarak değerlendirildi. Perkütan jejunal biyopsisi için girişimsel radyoloji ile görüşüldü ancak sağ üst kadranda peritoneal kalınlaşma tespit edilerek periton biyopsisi alındı. Periton biyopsi sonucu serözal yüzeylerin papiller karsinomu olarak rapor edildi. Hasta tedavi planı için medikal onkoloji bölümüne devir edildi. Hastaya paklitaksel ve karboplatinden oluşan kombine kemoterapi protokolü başlandı. 3 kür sonrası hastanın gerek şikayetleri gerekse jejunoileal duvar kalınlaşmasının belirgin şekilde azaldığı ve kontrol CA-125 düzeyinin gerilediği gözlemlendi.

\section{TARTIŞMA}

PSPK nadir görülen peritoneal yüzeyden kaynaklanan bir adenokarsinomdur. Hastalık ağırlıklı olarak abdomen ve

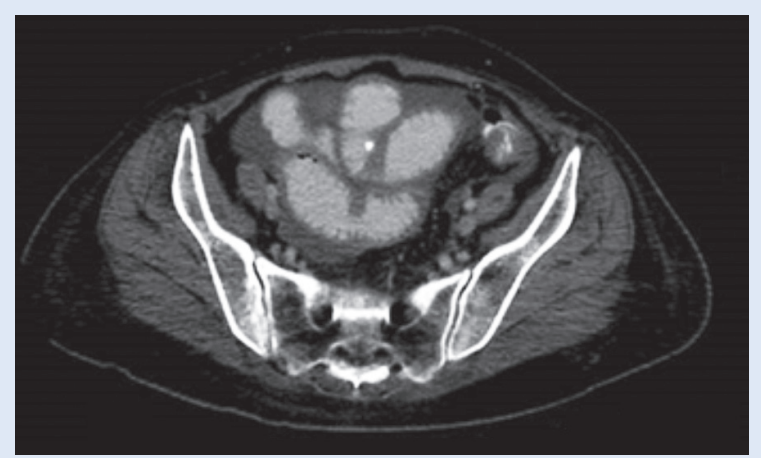

Resim 1. Ileal duvar kalınlaşması.

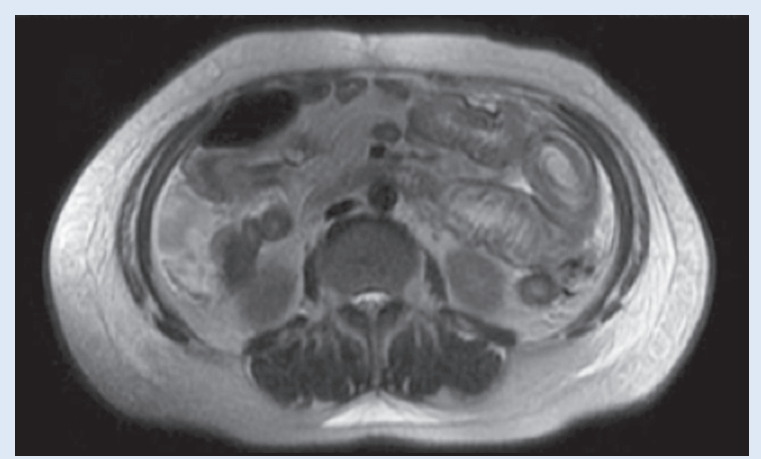

Resim 2. Jejunal duvar kalınlaşması. pelvik bölgenin peritoneal, mezenterik ve omental yüzeyinde görülür $(1,2)$.

PSPK gerek histolojik gerekse prognostik açıdan papiller seröz over adeno karsinomlarına (PSOK) benzer özelikler gösterebilir. Bu benzerliği açıklamak için 2 teori öne sürülmüştür. 1. teori: peritoneal karsinoma, overlerin embriyonik gelişimi süresince peritonun içerisinde kalan overial doku kalıntılarından orjin almaktadır, 2. teori: hem overial hem de peritoneal doku (mezodermal orjinli) müllerian sistem kaynaklıdır $(6,7)$. Jinekolojik Onkoloji Grubu tarafından PSPK'ı PSOK'dan ayırt etmek için tanı kriterleri tanımlanmıştır. Bunlar; her iki overin normal boyutta ya da benign bir lezyon nedeniyle normalden büyük olması, lezyonun her iki over yüzeyinden daha büyük olması, overyan tutulum varsa, over yüzeyinde veya korteksinde maksimum 5x5 mm'yi aşmayan implant varlığının olması ve tümörün histolojik ve sitolojik karakteristiğinin seröz tip ile uyumlu olmasıdır (8).

PSPK'ın görülme yaşı ortalama 55-65'dir. Hastalar karın ağrısı, abdominal distansiyon, abdominal kitle, asit ve subileus ile başvurabilir. Rapor edilen olguların \%70-90'ında CA-125'de anormal yükselme ve asit bulunmaktadır. Böylece CA-125 tedavi etkinliğinin takibinde ve nüksün erken tespitinde kullanılabilinir $(9,10)$. Morita ve arkadaşlarının yayınladıkları 11 PSPK'lı vaka serisinde; 9 hasta karın ağrısı, 7 hasta abdominal rahatsızlık, 5 hasta abdominal distansiyon, 3 hasta asit ve 3 hasta abdominal ele gelen kitle şikayetleri ile başvurmuş olup tüm hastalarda CA-125 seviyeleri artmış idi (10). Bizim hastamız da PSPK'nın jejunoileal duvar invazyonuna sekonder yaygın duvar kalınlaşmasına sekonder subileus şikayetleri ile başvurmuş olup hastamızın takiplerinde asit gelişmiştir. Literatürle uyumlu olarak bizim hastamızda da CA-125 seviyeleri yüksekti.

Olguların bilgisayarlı tomografi (BT) ve magnetik rezonans (MR) görüntülemelerinde asit, peritoneal kalınlaşma, peritoneal nodül, omental nodül veya kek, ve lenfadenopati en sık görülen bulgulardır $(9,11)$. Olguların \%20 -70'inde pelvik/retro-peritoneal lenf nodlarına, <\%15 visseral ve ekstraperitoneal lenf nodu yayılımı rapor edilmiştir (5). PSPK, nadiren de olsa intestinal duvarı invaze ederek intestinal kitlelere neden olabilmektedir. Literatürde günümüze kadar kolonda kitle (kolon karsinomu) ile prezente olan ve kötü diferansiye PSPK tanısı konulan yalnızca 3 olgu bildirilmiş olup ince bağırsak tutulumu şu ana kadar hiç bildirilmemiştir (12-14). Bizim olgumuzda PSPK'un jejunum orta kısmından başlayıp ileal duvarı yaygın bir şekilde infiltre ettiği gözlendi.

Jejunoileal duvar kalınlaşmasında ayırıcı tanıda; inflamatuvar nedenler (Crohn hastalığı), infeksiyöz nedenler (tü- 
berküloz, tifo, giardia, Yersinia enterocolitis), malignensi (lenfoma, sarkom), iskemi ve infarkt, vaskülit (sistemik lupus eritematozus, Henoch-Schönlein sendromu), intestinal ödem (nefrotik sendrom, siroz, protein kaybettiren enteropati), intramural hemoraji (hemofili, antikoagülan kullanımı) yer almaktadır (15). Hastamızın endoskopik bakIS ve biyopsisinde Crohn hastalığına ait bulgu izlenmedi. BT anjiyografisinde superior mezenterik arter ve ven açık olup duvar kalınlaşması hematom ile uyumlu değildi. Asit tüberküloz PCR negatif idi. Diğer nedenlerde dışlanarak peritoneal kalınlaşmadan biyopsi yapıldı ve hastamıza PSPK tanisı kondu.

PSPK'nın tedavisi stage III-IV seröz ovarian papiller kan-

\section{KAYNAKLAR}

1. Swerdlow M. Mesothelioma of the pelvic peritoneum resembling papillary cyst adenocarcinoma of theovary. Case report. Am J Obstet Gynecol 1959;77:197-200.

2. Halperin $R$, Zehavi $S$, Langer $R$, et al. Primary peritoneal serous papillary carcinoma: a new epidemiologic trend? A matched-case comparison with ovarian serous papillary cancer. Int J Gynecol Cancer 2001;11:403-8.

3. Shah IA, Jayram L, Gani OS, et al. Papillary serous carcinoma of the peritoneum in a man: a case report. Cancer 1998;82:860-6.

4. Shmueli E, Leider-Trejo L, Schwartz I, et al. Primary papillary serous carcinoma of the peritoneum in a man. Ann Oncol 2001;12:563-7.

5. Steinhagen PR, Sehouli J. The involvement of retroperitoneal lymph nodes in primary serous-papillary peritoneal carcinoma. A systematic review of the literature. Anticancer Res 2011;31:1387-94.

6. Kannerstein M, Churg J, McCaughey WT, Hill DP. Papillary tumour of the peritoneum in women: mesothelioma or papillarycarcinoma. Am J Obstet Gynecol 1977;127:306-14.

7. Lauchlan SC. The second mullerian system. Obstet Gynecol Surv 1972;27:133-46.

8. Bloss JD, Liao SY, Buller RE, et al. Extraovarian peritoneal serous papillary carcinoma: a case-control retrospective comparison to papillary adenocarcinoma of the ovary. Gynecol Oncol 1993;50:347-51.

9. Chiou SY, Sheu MH, Wang JH, Chang CY. Peritoneal serous papillary carcinoma: a reappraisal of $\mathrm{CT}$ imaging features and literature review. Abdom Imaging 2003;28:815-9. serler ile benzerdir. Tedaviyi; platinyum temelli kemoterapiyi takiben histerektomi, salpingoferektomi ve omentektomiyi içeren debulking cerrahi oluşturur (16). Bizim hastamı da paklitaksel ve karboplatinden oluşan kombine kemoterapi aldı. 3 kür kemoterapi sonrası hastanın jejunoileal duvar kalınlaşması belirgin şekilde azaldı ve yükselmiş olan CA-125 seviyelerinin normale döndüğü izlenmiştir.

Sonuç olarak orta-ileri yaşta kadın hastalarda peritoneal karsinomatozis varlığında tespit edilebilir bir malignensi yokluğunda ve normal over durumunda PSPK akla getirilmelidir. Nadiren de olsa ince bağırsaklarda duvar kalınlaşmasına neden olabileceği düşünülmelidir.
10. Morita H, Aoki J, Taketomi A, et al. Serous surface papillary carcinoma of the peritoneum: clinical, radiologic and pathologic findings in 11 patients. Am J Roentgenol 2004;183:923-8.

11. Voultsinos V, Semelka RC, Elias J Jr, et al. Primary peritoneal carcinoma: computed tomography and magnetic resonance findings. J Comput Assist Tomogr 2008;32:541-7.

12. Chand M, Moore PJ, Clarke AD, et al. A diagnostic dilemma following risk-reducing surgery for BRCA 1 mutation-a casereport of primary papillary serous carcinoma presenting as sigmoid cancer. World J Surg Oncol 2007;5:102.

13. Kim HS, Sung JY, Park WS, et al. Primary peritoneal serous papillary carcinoma presenting as a single colonic mass without peritoneal dissemination. Intern Med 2013;52:227-32.

14. Tran TA, Holloway RW. Primary peritoneal low-grade serous carcinoma forming a mass in the colon mimicking a colonic primary carcinoma: a case report. Eur J Gynaecol Oncol 2013;34:86-9.

15. Eisenberg RL. Thickening of small bowel folds. AJR Am J Roentgenol 2009;193:W1-6.

16. Pentheroudakis G, Pavlidis N. Serous papillary peritoneal carcinoma: Unknown primary tumour, ovarian cancer counterpart or a distinct entity? A systematic review. Crit Rev Oncol Hematol 2010;75:27-42. 